\title{
PEMBELAJARAN SEJARAH DI ERA REVOLUSI INDUSTRI 4.0 (SEBUAH AITERNATIF)
}

\author{
Dewa Agung G.A.
}

\begin{abstract}
Abstrak.
Revolusi Industri 4.0 berpengaruh terhadap sejarah baik secara substansi yang menyebabkan semakin kompleksnya sumber-sumber sejarah maupun proses belajarannya. Perkembangan tersebut mulai dari metode, media, model pembelajaran yang bersifat inovatif, sampai dengan substansi materinya sering menimbulkan kontroversial. Perkembangan teknologi seakan dunia ini sudah ada digenggaman kita sehingga dengan mudah berbagai informasi kesejarahan dapat diperolehnya. Pebelajaran sejarah tidak mungkin mengabaikan semua itu, walaupun tidak semuanya berdampak positif bagi siswa/mahasiswa sejarah, guru sejarah, maupun sejarawan. Mereka hendaknya bisa selektif dalam menyikapi berbagai perkembangan akan ketersediaan informasi kesejarahan. Kolaborasi dan elaborasi antara sejarah dengan bidang ilmu yang lain terus dilaksanakan untuk melihat berbagai perubahan dan perkembangan (change and development) dimasyarakat dalam berbagai bidang. Apakah perkembangan di bidang ekonomi, politik, sosial dan budaya sehingga sejarah tidak bersifat mono-perspektif, tetapi multiperspektif. Dengan demikian pembelajaran sejarah akan memberikan informasi yang komprehensip, integrited, dan itulah disebut sejarah total (total history). Tidak ada cara yang terbaik dalam proses pembelajaran sejarah, karena itu tulisan ini memberikan salah satu alternative bagaimana pembelajaran sejarah di Era Revolusi Industri 4.0.
\end{abstract}

Kata Kunci: Pembelajaran Sejarah, RevolusiIndustri 4.0

\section{Pendahuluan}

Perkembangan teknologi informasi mempunyai pengaruh di segalal ini kehidupan, walaupun awalnya perkembangan tersebut dirasakan di lembaga-lembaga yang bergerak di bidang ekonomi (perusahaan). Begitu juga Revolusi Industri 4.0 membawa dampak tidak hanya pada pendekatan baru tetapi juga metodologi dan teknologi pada perusahaan, yang dalam perkembangannya berpengaruh juga diberbagai ilmu pengetahuan. Karenanya sudah waktunya diperkenalkan kepada masyarakat, utamanya akademisi (Benesovaa \& Tupaa, 2017:2195). Menurut Baygin, dkk bahwa Revolusi Industri 4.0 dapat didefinisikan sebagai "pabrik pintar", Internet of Things. Industri 4.0, muncul di bawah kepemimpinan Jerman,dan merupakan istilah yang pertama kali digunakan pada 2011. Pada awal kelahirannya konsep Industri 4.0, sangat cocok untuk ilmu teknik dasar seperti komputer, elektronik dan teknik mesin, namun demikian mengingat internetituteknologi yang aktif digunakan dalam pendidikan tinggi sehingga secara langsung akan berpengaruh juga terhadap segala aktvitas di perguruan tinggi(Baygin, Yetis, 
Karakose, \& Akin, 2016).Andrey mengatakan perkembangan teknologi dan informasi suatu keharusan sehingga setiap pengguna harus mengikutinya sebagai pendekatan dalam generasi human digital yaitu menitik beratkan pada pendekatan yang berbasis keahlian digital. Karena itu diperlukan beberapa kompetensi yang dipersiapkan era industri 4.0 diantaranya adalah kemampuan memecahkan masalah (problem solving), beradaptasi (adaptability), kolaborasi (collaboration), kepemimpinan (leadership), dan kreatifitas serta inovasi (creativity and innovation). (Harususilo, 2018).

Pembelajaran sejarah hendaknya berusaha selalu berinovatif senyampang dengan perkembangan teknologi kalau tidak ingin ketinggalan jaman. Sebenarnya semua ini sangat dilematis karena tidak semua pengajar sejarah mempunyai kemampuan dalam mengikuti perkembangan teknologi dan ketersediaan serta kesiapan perangkat lunak yang menyertainya di setiap sekolah. Kalau ini dipaksakan maka akan memunculkan "cerita seribu satu seorang guru”, bahwa "pendekatan, metode dengan berbagai model-model pembelajaran yang inovatif dapat disalah gunakan oleh seorang guru untuk menutupi ketidak mampuan mengajar". Padahal kalau berbicara mengajara dalah "seni" dan media yang utama adalah guru itu sendiri yang sudah seharusnya dapat menyampaikan materi pembelajaran dalam kondisi apapun. Seperti yang dikatakan oleh Gerlach dan Ely, secara umum mengenal bernagari bentuk dan jenis media, tetapi yang terpenting adalah "pengajar". Sedang secara lebih khusus, pengertian media dalam proses belajar mengajar cenderung diartikan sebagai alat-alat grafis, photografis, atau elektronis untuk menangkap, memproses, dan menyusun kembali informasi visual atau verbal (Gerlach \& Ely, 1980). Dari pandangan tersebut "pengajar" dalam hal ini "manusia" yang berprofesi sebagai "guru" adalah media yang utama. Namun demikian akan lebih sempurna kalau seorang guru sejarah mempunyai kompetensi dibidang teknologi sehingga menjadi digital human selain kompetensi profesional, pedagogik, sosial, dan kepribadian sesuai dengan Permen Diknas No. 16 Tahun 2007. Bahkan menurut penulis seorang guru harus juga harus mempunyai "kompetensi religius".

\section{Revitalisasi Pembelarajan Sejarah di Era Revolusi Industri 4.0}

Tragis memang sampai sekarang masih terdapat kesan bahwa pembelajaran sejarah membosankan karena hafalan nama-nama tokoh, tahun, dan sebagainya, itu semua adalah masalah klasik. Padahal mencermati "sejarah pembelajaran sejarah", bahwa mata pelajaran 
sejarah menduduki posisi sejak zaman Pergerakan Indonesia dan sudah diperkenalkan oleh Partai Nasional Indonesia tahun 1927 (Dekker, 1975:56). Dengan datangnya era Revolusi Industri 4.0 memunculkan permasalah baru lagi yaitu bagaimana dengan perkembangan teknologi informasi seorang pengajar sejarah mampu menggunakan teknologi dengan tepat guna dan menyampaikan materi sejarah yang berdaya guna. Dengan perkembagan teknologi informatika berbagai informasi dapat diakses oleh siapa saja melalui media sosial, semua informasi tidak mungkin ditutupi. Kondisi semacam ini seorang guru sejarah sudah seharusnya meningkatkan berbagai kompetensinya. Menurut Mc Cullagh, bahwa seorang sejarawan harus memperlajari berbagai perubahan dan menjawab berbagai tantangan. Perubahan struktur sosial dari masyarakat agraris yang feudal kemasyarakat yang kapitalis industri yang kapitalis, dan perlu ada interpretasi kritis terhadap berbagai sumber/bukti dalam menulis sejarah yang professional. (Mc Cullagh, 2004:297).

Diperlukan berbagai cara untuk mengatasi perubahan tersebut, diantaranya perlu adanya proses "literasi" yang terus menerus baik yang berkaitan dengan perkembangan teknologi maupun pengetahuan sejarah dan perkembangan ilmu lainnya. Literasi yang bersifat digital di masa sekarang sangat diperlukan dengan harapan proses pendidikan dan pembelajaran itu menjadi lebih kolaboratif dan elaboratif. Semuaini dengan tujuan tidak hanya untuk meningkatkan pengetahuan siswa, tetapi mendukung mereka untuk memperkuat kepribadian, dan mengembangkan potensi serta kompetensi yang dimiliknya untuk menuju dunia kerja (Schuster, Plamannis, \& Grob, 2015:10-14). Informasi dari internet hendaknya diposisikan sebagai program "internet sehat" merupakan salah satu model strategi advokasi tentang "etika online" dan literasi digital untuk masyarakat. Untuk itu internet sehat memperkenalkan bagaimana para "orang tua" dan "guru" tahun tentang pengetahuan dasar internet, penggunaan internet, bahaya internet, serta literasi informasi, keamanan dan perlindungan privasi (Rizky, dkk, 2018 :33). Marshall Maposa \& Johan Wassermann, membedakan antara "literasi dalam sejarah" dan "literasi historis". Literasi dalam sejarah mengacu pada kemampuan membaca dan menulis saat mempelajari sejarah, sedangkan litarasi historis menyiratkan apa yang didapatkan seseorang dari mempelajari sejarah hendaknya disesuaikan dengan konteks ruang dan waktu (Mapora \& Wassermann, 2009:62). Karena itu pendidikan nasional harus dijalankan secara kontekstual dan fungsional, Pendidikan kita harus berakar pada aspirasi dan kebutuhan masyarakat pendukungnya yang secara sosial budaya dan lingkungan alamiahnya. Oleh karena 
itu Pendidikan di abad 4.0 perlu ditanamkan nilai-nilai kewarganegaraan (good citizen), kekaryaan (good worker), dan nilai kemanusiaan (good human) (Abduhzen, 2018).

Sebenarnya sejak awal 1970-an, para sejarawan sudah menjadikan mata pelajaran sejarah semakin inter disiplin dan multi disiplin, sehingga bersifat semakin integrated, cara semacam ini sangat bermanfaat untuk literasi sejarah (Limage, 2005:2-4). Literasi juga terkait dengan perkembangan filsafat ilmu yang sedemikian rupa sehingga perlu pengenalan terhadap teori-teori aliran modern sampai post modern. Perkambangan tersebut menyebabkan semakin sempitnya jurang pemisahan tarilmu satu dengan yang lain. Semakin mendekat, dengan demikian diharapkan terjadi integrasi (integrated) atau paling tidak terja dikoneksi (connecting) antar bidang ilmu. Sartono Kartodirdjo sudah lama memperkenalkan apa yang disebut dengan sejarah kritis, analitis, dan multi dimensional dengan pendekatan ilmu-ilmu sosial untuk mewujudkan total history (Purwanto \& Adam, 2005:4).

Konvergensi ilmu pengetahuan dan teknologi terus terjadi sejak abad ke-21 yang membuat persinggungan dan integrasi yang bersifat multi disiplin, antar disiplin, bahkan transdisi sehingga ilmu pengetahuan menjadi nyata. Persinggungan tersebut akan membuahkan area kajian baru untuk penguatan disiplin ilmu yang bersangkutan, atau membuahkan area kajian disiplin baru (Kamdi, 2016:6). Sebagai contoh bagaimana sejarah dipersingungkan dengan sosiologi. Seperti pandangan Burke dalam "Sejarah dan TeoriSosial”, bahwa "sejarah adalah fakta sosial, itulah sosiologi yang sebenarnya" (Burke, 2001:10). Weber adalah tokoh yang mempelajari sosiologi melalui pintu sejarah, baginya "sosiologi adalah suatu kenyataan sejarah" (Arisandi, 2015:64). Dalam perkembangannya, sejarah tidak hanya bersifat diakronis, tetapi menuju kearah tulisan yang analitis dan sinkronis, walaupun perspektif sinkronis lazimnya ditemui dalam penelitian-penelitian sosiologi (Kuntowijoyo, 2003:24). Buku Charles Tilly dengan judul "As Sociology Meets History" dikatakan, bahwa apa bila seorang peneliti melakukan penelitian lapangan, tidak bisa lepas dari pertanyaan-pertanyaan yang terkait dengan latar kesejarahan suatu komunitas (Tilly, 1981:29-30). Christopher Lloyed, bahwa pandangan tokoh-tokoh seperti Marx, Enggels, Spencer, Durkheim, Sombart, dan Broudel, percaya bahwa sejarah sebagai struktur yang berkontribusi terhadap ilmu-ilmu sosial (Lloyed, 1987:19). Schrie kedalam bukunya yang berjudul Indonesian Sociological Studies, yang membahas tentang kedatangan Islam sampai dengan perkembangan Komunis di Indonesia, menggunakan pespektif sosilogis dengan melihat struktur masyarakat setempat (Schrieke, 1960). 
Tulisan Sztompka dalam bukunya "Sosiologi Perubahan Sosial", diantaranya, dalam keanekaragaman pemikiran sosiologi (kontemporer), orientasi historis jelas masih besar pengaruhnya (Sztopkam, 2014:248-249). Diakui, bahwa masyarakat tidak dapat membangun masyarakat seperti yang mereka inginkan, tetapi mereka membangunnya berdasarkan kondisi struktur yang mereka warisi dari masa lalu. Sztompka juga merujuk tulisan Chritopher Lloyd (Sztopkam, 2014:247-248) berpendapat, akan pentingnya kajian sejarah terhadap struktur dan tindakan individu. Dijelaskan bahwa:

,“....masa kini selalu menjadi masa lalu, dan proses terus ada di kedua arah itu,.... karena struktur senantiasa berubah, maka ia harus selalu dikaji secara historis,...." tindakan dapat dijelaskan melalui strukturnya dan sejarahnya sebagai akibat tindakan individu yang diinginkan atau tak diinginkan dan pola perilaku massa sepanjang waktu,......tindakan individu dan kolektif merupakan agen fundamental sejarah,.....konsepsi struktur ini melihat masyarakat sebagai kesatuan yang teratur, bebas tetapi terintegrasi dengan longgar, sebagai antar hubungan yang terus-menerus berubah, dan sebagai aturan dan peran yang mengikat kolektifitas menusia individu secara bersama. Keberadaan masyarakat bukan sekedar penjumlahan individu bebas yang menjadi anggotanya. Agar tetap hidup, masyarakat harus direproduksi secara kolektif oleh individu anggotanya dan berpotensi besar untuk diubah menjadi struktur yang bebas dari tindakan anggotanya".

Dalam penelitian sejarah menurut Neuman dikenal historical-comporative research yang mempunyai keunikan karena mengkomperasikan antara sejarah dengan ilmu-ilmu sosial, adanya integrasi antara level mikro dan makro, (Neuman, 2009:297). Mengintegrasikan tingkat mikro (interaksi tatap muka berskala kecil) dengan tingkat makro (struktur sosial berskala besar), bukan hanya menggambarkan proses tingkat mikro atau makro secara tersendiri, tetapi peneliti juga menelaah dan menghubungkan berbagai tingkat dari kenyataan atau empirik di lapangan (Neuman, 2009:299). Kondisi semacam inilah yang menurut Kumar, dikenal dengan nama "sosiologis historis" (Kumar, 2012:662).

Mengikuti perkembangan filsafat ilmu bahwa sejarah tidak lagi disikapi sebagai hasil““ rekonstruksi" dan "re-kreasi", tetapi sebagai hasil "dekonstruksi". Berbicara dekonstruksi kita dihadapkan pada konsep filsafat posmoder menisme. Seperti yang dikatakan oleh Lubis bahwa dekonstruksi sebagai sebuah metode sebagai upaya untuk mengkritisi secara radikal dan membongkar berbagai asumsi-asumsi dasar yang menopang pemikiran dan keyakinan kita sendiri. Melakukan kritik terhadap pandangan lama dengan berbagai pikiran dengan mengajukan argument baru yang menuntutnya lebih dapat diterima dan dipertanggung jawabkan (Lubis, 
2014:33-35). Habermas dengan teori kritis dan teori tindakan yang banyak melakukan kritik terhadap pemikiran-pemikiran pendahulunya seperti pemikiran Marx, karena itu Habermas mengatakan terdapat tiga kepentingan ilmu pengetahuan yaitu; kepentingan teknis (empiris, analisis), praktis (pemahanmakna), dan emansipatoris (refleksidiri) (Arif, 2014:31-32). Perkembangan teknologi informasi sebagai salah satu unsur kebudayaan akan berpengaruh terhadap praktik-praktik sosial yang menyebabkan munculnya peristiwa-peristiwa yang bersentuhan dengan manusia (human) tentu tidak bisa dielakkan. Kondisi semacam inilah akan tercatat sebagai sejarah dimasa yang akandatang. Karena itu sejarah sebagai pendidikan dan pemebelajaran merupakan proses adaptasi terhadap lingkungan sosio-kultural sehingga pendidikan dan pembelajaran sejarah menekankan pada peranan bangsa Indonesia dalam bidang sosio-kultural dari abad keabad (Kartodirdjo, 1970:49-55).

Menurut Kuntowijoyo, sejarawan Indonesia perlu menjadikan sejarah sebagai "kritik sosial", sehingga sejarah sebagai hasil sebuah rekonstruksi dan sejarawannya tidak hanya sekedar menjadi alat pembenar dan menara gading, atau hanya mampu berdialog dengan dirinya sendiri dan takut pada penindasan serta kelaziman politik (Purwanto, 2006:47). Berdasarkan pandangan tersebut seorang pembelajar sejarah dengan terbukanya akses terhadap sumbersumber sejarah akibat perkembangan teknologi informasi dapat semakin kritis yang diharapkan dapat melaksanakan dekonstruksi. Pendidikan kritis transformasi fitulah yang digunakan di berbagai perpektif pendidikan seperti konstruksi kurikulum, penerapan pembelajaran, evaluasi, sampai penelitian pendidikan (Widja, 2012: 3). Sejarah sebagai ilmu yang selalu berusaha seobjektif mungkin, atau paling tidak mendekati objektif. Sejarah adalah perkembangan roh dalam waktu, roh adalah "kebebasan", manusia adalah bagian dari alam dan bagian dari roh (Hegel, 2005:xliii). Karena sejarah adalah ilmu, maka sejarah adalah hasil nalar, nalar adalah hukum dunia yang terjadi secara rasional (Hegel, 2005:15).

Perkembangan teknologi informasi menyebabkan informasi substansi sejarah sudah seperti bola liar di media sosial, apakah ini sebagai upaya pelurusan sejarah atau pembengkokan sejarah. Padahal sejarah tidak perlu diluruskan karena sejarah akan meluruskan dirinya sendiri (Puranto \& Adam, 2005:12). Pasca reformasi tahun 1998 penulisan sejarah sangat heboh, apalagi di media sosial. Muncul berbagai informasi yang membawa lebel kontroversial. Setiap orang dapat menulis apa saja, dengan kepentingan tertentu sehingga dalam kondisi semacam ini seorang pengajar sejarah secara substansi alemen dapat tantangan baru dalam menyampaikan 
materi sejarah. Dalam kondisi semacam ini pengajar sejarah hendaknya mengetahui dan mampu menyelesaikan masalah tersebut, tentu dengan semakin meningkat kompetensi professional melalui proses literasi diri dan memper banyak membaca referensi.

Di media sosial terdapat informasi materi sejarah yang bersifat kontroversial, seperti peristiwa sekitar tokoh DI/TII dan peristiwa sparatis lainnya, peristiwa G 30 SPKI tahun 1965, Supersemar dan sebagainya dengan berbagai silang pendapat siapa dalang dibalik peristiwa tersebut. Pertanyaan-pertanyaan sekitar substansi tersebut tidak lah mudah dijawab kalau seorang pengajar sejarah tidak membekali diri dengan berbagai referensi dan mengetahui akan hal tersebut terdapat di media sosial. Walaupun pada akhirnya akan kembali pada sejarah yang bersifat Indonesia sentris. Karena menurut Sartono Kartodirdjo bahwa berbicara penulisan sejarah nasional terkait dengan simbol-simbol identitas bangsa, mecari jati diri bangsa berdasarkan ideology bangsa (Kartodirdjo, 2001:67). Satu sisi sejarah sebagai dasar kesadaran sejarah yang fungsinya untuk memperkokoh identitas nasional atau kolektif (Nordholt, 2008, p. 1). Dan penulisan sejarah Indonesia berfungsi untuk membenarkan atau mengesahkan keberadaan komunitas atau bangsa (Kartodirdjo, 2001: 80). Memang penyelengara pendidikan tidak bisa lepas dari kepentingan politik, sistem sosial ekonomi maupun kekuasaan yang ada sehingga substansi pendidikan tidak lebih dari sebagai sarana untuk mereproduksi sistem dan struktur sosial yang tidak adil seperti rasisme, gender, karena itu disebut dengan "reproduksi" pendidikan (Arif, 2014:239-240). Begitu juga kajian sejarah kontroversial di ranah pendidikan menjadi penting kalau pendidikan kita tidak dikatakan out of context, karena seolah-olah tidak mengakomodasinya, pada hal penulisan sejarah bersifat evolusi (Azimar, 2016: xvi)

\section{Simpulan}

Era Revolusi Industri 4.0 membawa dampak besar bagi pembelajaran sejarah baik terkait dengan pengguaan media, metode, berbagai model pembelajaran, substansi sejarah yang tidak hanya terdapat buku-buku cetak, tetapi di media sosial. Satu sisi semua ini akan menjadi rahmat, tetapi satu sisi aka nmenjadi musibah kalau pengajar sejarah tidak selektif dan selalu meningkatkan kompetensinya. Karena itu diperlukan beberapa kompetensi yang dipersiapkan era industri 4.0, selain kompetensi yang diamanatkan oleh Permendiknas No.16 Tahun 2017. Kompetensi tersebut adalah kemampuan memecahkan masalah (problem solving), beradaptasi (adaptability), kolaborasi (collaboration), kepemimpinan (leadership), dan kreatifitas serta 
inovasi (creativity and innovation). Apapun perubahan yang terjadi sejarah tetap menjadi mata pelajaran yang vital karena secara substansial sejarah adalah pengalaman hidup bangsa,sehingga ada pribahasa "pengalaman adalah guru yang utama". Sehingga dengan mempelajari pengalaman hidup tersebut akan menjadi orang yang bijaksana karena masa lalu sebagai cermin untuk bertindak dimasa sekarang dan masa yang akan datang.

Berbagai informasi sejarah melalui media sosial hendaknya dipakai sebagai referensi

untuk berdialog dalam upaya objektivitas, atau paling tidak mendekati objektivitas sejarah. Sejarah mempunyai posisi yang starategis sebagai kritik sosial dan budaya karena dengan perkambangan teknologi informasi tidak mustahil akan menyebabkan perubahan-perubahan yang mendasar dalam kehidupan berbangsa dan bernegara. Proses dekonstruksi terhadap perubahan tersebut perlu dilakukan sehingga pembelajaran sejarah tidak hanya terbuai dengan hasil rekonstruksi dan re-kreasi seseorang. Dengan demikian perkembangan teknologi di Era Revolusi 4.0 dapat dimitra sejajarkan dalam proses inovasi diberbagaihal dalam pembelajaran sejarah.

\section{DAFTAR PUSTAKA}

Abduhzen, M. (2018). Pendidikan yang Fungsional. Jakarta: Kompas, 13 Agustus 2018.

Arif, M. (2014). Pendidikan Posmodernisme. YogyakartA: AR-RUZZ MEDIA.

Arisandi, H. (2015). Buku Pintar Pemikiran Tokoh-Tokoh Sosiologi Dari Klasik sampai Modern . Yogyakarta: IRCiSoD.

Azimar, A. T. (2016). Sejarah Kontroversial di Indonesia: Perspektif Pendidikan. Jakarta: Yayasan Obor Indonesia.

Baygin, M., Yetis, H., Karakose, M., \& Akin, E. (2016). An Effect Analysis of Industry 4.0 to Higer Education. American Journal of Speech-Language Pathology.

Benesovaa, A., \& Tupaa, J. (2017). Education and Qualitative of Paople in Industry. 27th International Conference on Flexible Automation and Intelligent Manufacturing, 2195.

Burke, P. (2001). Sejarah dan Teori Sosial. Jakarta: Yayasan Obor Indonesia.

Dekker, I. N. (1975). Sejarah Pergerakan Nasional Indonesia. Malang: Almamater.

Gerlach, \& Ely. (1980). Teaching \& Media: A Systematic Approach. Boston: Pearson Education.

Harususilo, Y. E. (2018, Mei Rabu). "Ki Hajar Dewantara dan Guncangan Pendidikan Era Industri 4.0". Retrieved from https://edukasi.kompas.com/read/ 2018/05/02/ 15561621/ki-hadjar-dewantara-dan-guncangan-pendidikan-era-industri-40

339 | Seminar Nasional Sejarah ke 4 Jurusan Pendidikan Sejarah Universitas Negeri Padang 
Hegel. (2005). Nalar dalam Sejarah. Jakarta: Teraju.

Kamdi, W. (2016). Inovasi Pendidikan Tinggi. Malang: UM Press.

Kartodirdjo, S. (1970). Lembar Sejarah. Yogyakarta: UGM Press.

Kartodirdjo, S. (2001). Indonesian Hitoriography. Yogyakarta: Kanisius.

Kartodirdjo, S. (2001). Writing Nasional History in Indonesia, Theory and Practice. Yogyakarta: Kanisius.

Kumar, K. (2012). Sosiologis Historis. In B. s. Turner, Teori Sosial Dari Klasik Sampai Postmodern (p. 662). Yogyakarta: Pustaka Pelajar.

Kuntowijoyo. (2003). Metodologi Sejarah. Yogyakarta: PT. Tiara Wacana.

Limage, L. (2005). 2. The growth of literacy in historic perspective: clarifying the role of formal schooling and adult learning opportunities. United Nations Educational, Scientific and Cultural Organization., 2-4.

Lloyed, C. (1985). Explanation in Social History. New York: Basil Blackwell.

Lloyed, C. (1987). Teori Sosial dan Praktek Politik. Jakarta: Aksara Persada Indonesia.

Lubis, A. (2014). Posmodernisme, Teori dan Metode. Jakarta: PT. RajaGrafindo Persada.

Mapora, M., \& Wassermann, J. (2009). Conceptualising historical literacy - a review of the literature. Yesterday\&Today, 62.

McCullagh, C. (2004). Logic of History, Perspektif Posmodernisme. Yogyakarta: Lilin Persada Press.

Neuman, W. L. (2009). Understanding Research. Sydney: Pearson.

Nordholt, H. (2008). Perspektif bar Penulisan Sejarah Indonesia. Jakarta: Yayasan Obor.

Puranto, B., \& Adam, A. (2005). Menggugat Historiografi Indonesia. Yogyakarta: Ombak.

Purwanto, B. (2006). Gagalnya Historiografi Indonesiacentris ?! Yogyakarta: Ombak.

Rizky, C. (2018). Media Sosial untuk Advokasi Publik. Jakarta: ICT Watch.

Schrieke, B. (1960). Indonesian Sosioloical Studies. Bandung: 1960.

Schuster, K., Plamannis, L., \& Grob, K. (2015). 3. Preparing for Industry 4.0 - Testing Collaborative Virtual Learning Environments with Students and Professional Trainers. RWTH Aachen University, Germany, 10-14.

Sztopkam, P. (2014). Sosiologi Perubahan Sosial. Jakarta: Prenadamedia Group.

Tilly, C. (1981). As Socilogi Metts History. Orlanda Florida: Academy Press.Inc. 
Widja, I. G. (2012). Pendidikan Sebagai Ideologi Budaya, Mengamati Permasalaahan Pendidikan Melalui Kajian Budaya. Denpasar: Krishna Abadi. 